\title{
The Effects of Temperature and Humidity around the Beehives on the Distribution of Nosema ceranae, and also Geographical and Seasonal Activity of the Infection in the Eastern Black Sea Region of Turkey
}

\author{
Onur Tosun $^{1}$ and Mustafa Yaman ${ }^{2}$ \\ 1. Giresun University, Alucra Turan Bulutçu Vocational School, Giresun 28700, Turkey \\ 2. Karadeniz Technical University, Department of Biology, Trabzon 61080, Turkey
}

\begin{abstract}
Eastern Black Sea Region of Turkey and samples were collected from around the beehives from April to September. Total of 4,640 dead adult worker bees were examined during the study. Total infection rate in worker bees was $21.23 \%$. Nosema ceranae was identified in all localities with molecular techniques. Temperature and humidity values were measured from around the beehives during field studies. The infection rate of $N$. ceranae increased proportionally with increasing temperature and humidity factors. Humidity was more effective than temperature on the infection rate of $N$. ceranae. The seasonal activity of $N$. ceranae was studied. The highest infection rates were observed in June and July. $N$. ceranae infection rate was higher in localities that were in low-altitude than in localities that were in high-altitude.
\end{abstract}

Key words: Temperature, humidity, geographical distribution, Nosema ceranae, Apis mellifera, Turkey.

\section{Introduction}

Apis mellifera is economically the most important bee for beekeeping in the world wide [1]. Turkey is one of the leading countries in the world in terms of honey production, despite Turkey has low levels in honey production per hive $[2,3]$. One of the biggest reasons is diseases that directly affect the health of bees. In order to control these illnesses, disease factors must be examined well.

For several decades, Nosema apis was only known causal agent of Nosemosis in western honey bee Apis mellifera [4]. However, later studies have showed that $N$. ceranae, originally found in the Eastern honey bee Apis cerana [5], infects European honey bee $A$. mellifera $[6,7]$.

Black Sea Region has a significant percentile

Corresponding author: Onur Tosun, Ph.D., assistant professor, main research field: entomology. approximately $50 \%$ in terms of honey production in Turkey [2, 3]. There are few studies about the Nosemosis disease in Turkey. Especially, there are no studies on the resistance of temperature and humidity factors, additionally the seasonal distribution of $N$. ceranae infection in Turkey.

Knowing the effect of environmental factors on disease factor would provide important information for the control of disease. Temperature and humidity around the beehives were the most important environmental conditions that cause quickly spread of the infection in honeybees. In this study, temperature and humidity factors around the beehives at the natural environment were studied through the effect on the distribution of $N$. ceranae infection. Additionally, seasonal activity and geographic distribution of $N$. ceranae infection were reported in Eastern Black Sea Region of Turkey for the first time. 
514 The Effects of Temperature and Humidity around the Beehives on the Distribution of Nosemaceranae, and also Geographical and Seasonal Activity of the Infection in the Eastern Black Sea Region of Turkey

\section{Materials and Methods}

\subsection{Sample Collection}

20 different localities randomly in 7 different provinces from the Eastern Black Sea region of Turkey were determined (Table 1). The adult dead worker bees were collected in front of the hives from April to September in 2011. The humidity and temperature meterdevices were placed around the bee hives. 3 times a day, temperature and humidity data were determined on a daily basis.

Samples were dissected in Ringer's solution. Wet smears were examined under a light microscope at a magnification of $400-1,000 \times$. Spore purification and PCR amplification conditions

Positive samples were collected in sterile $1.5 \mathrm{~mL}$ micro centrifuge tubes. Samples micro centrifuge tubes were completed to $1 \mathrm{~mL}$ with distilled water. The filtered suspension was centrifuged for $6 \mathrm{~min}$ at 3,200 rpm. The suspension was rinsed with $1 \mathrm{~mL}$ distilled water. Spores were counted with a hemocytometer $\left(2.8-5.3 \times 10^{7} / \mathrm{mL}\right)$. Purified spores were stored at $-20{ }^{\circ} \mathrm{C}$ until DNA extraction process [8].

Total 20 suspension samples were collected in amicro centrifuge tube for each locality and prepared for molecular characterization procedures. DNA was extracted according to the procedure $[6,9,10]$ using the "DNeasy Blood \& Tissue Kit" (QIAGEN, Cat. no. 69504). $50 \mu \mathrm{L}$ PCR reaction mixture was prepared using “Qiagen Multiplex PCR Kit” (QIAGEN, Cat. no. 206143). PCR was performed following the procedure previously described by Ref. [9]. All the primer sets: 321 APIS

FOR (5'-GGGGGCATGTCTTTGACGTACTATGTA-3'), and 321 APIS REV (5'-GGGGGGCGTTTAAAATGTGAAAC

AACTATG-3') (N. apis, 321 bp fragment of the $16 \mathrm{~S}$ rDNA) [9]; 218 MITOC (5'-CGGCGACGATGTGATATGAAA-ATATTAA-

3') and 218 MITOC REV

(5'-CCCGGTCATTCTCAAACAAAA-AACCG-3')

( $N$. ceranae 218-219 bp region of the $16 \mathrm{~S}$ rDNA) [9]; NosA-F (5'-CCGACGATGTGATATGAGATG-3') and NosA-R

(5'-CACTATTATCATCCTCAGATCATA-3') (N. apis 209 bp fragment of the 16S rDNA) [11]; NOS-FOR (5'-TGCCGACGATGTGATATGAG-3') and

NOS-REV

(5'-CACAGCATCCATTGAAAACG-3') (N. apis $240 \mathrm{bp}$ fragment of the $16 \mathrm{~S}$ rDNA) [6] were used one by one for PCR.

PCR was programmed as activation step of 2 minutes at $94{ }^{\circ} \mathrm{C}$, followed by 10 cycles of 15 seconds at $94{ }^{\circ} \mathrm{C}, 30$ seconds at $61.8{ }^{\circ} \mathrm{C}$, and 45 seconds at $72{ }^{\circ} \mathrm{C}$, and 20 cycles of 15 seconds at $94{ }^{\circ} \mathrm{C}, 30$ seconds at $61.8{ }^{\circ} \mathrm{C}$, and 50 seconds at $72{ }^{\circ} \mathrm{C}$ plus a 5 -second elongation cycle for each successive cycle and a final extension step at $72{ }^{\circ} \mathrm{C}$ for 7 minutes. Negative controls (from DNA extraction) were included in all PCR reactions [9]. The molecular weights of PCR products were determined by electrophoresis in a $0.9 \%$ agarose gel stained with ethidium bromide, and visualized using UV illumination.

\section{Statistical Analysis}

Between 2009 and 2011, total of 102 times locality study was performed. In this study, in all locality data of Nosema disease infection were obtained according to the provinces, the difference the altitude of localities, temperature change and humidity change around the beehives. The data obtained in this study were compared with correlation and regression analysis using SPSS 11.0 software [12].

\section{Results}

Worker bees were examined in Eastern Black Sea of Turkey in 2011. 985 of 4,640 (21.23\%) dead worker bees which infected with $N$. ceranae were observed. Temperature and humidity data were reported separately for each locality. 
The Effects of Temperature and Humidity around the Beehives on the Distribution of Nosemaceranae, 515 and also Geographical and Seasonal Activity of the Infection in the Eastern Black Sea Region of Turkey

While the lowest temperature datum was determined as $11.7^{\circ} \mathrm{C}$ in May in Gümüşhane center localitythat it has $12 \%$ infection rate, the highest temperature datum was determined as $38.9^{\circ} \mathrm{C}$ in of locality that infection rate was $52 \%$ in July (Table 1). When temperature was in the range of 11-15 ${ }^{\circ} \mathrm{C}$, average $N$. ceranae infection rate was around $10 \%$. With increasing temperature (the range of $15-30{ }^{\circ} \mathrm{C}$ ), infection rate showed an increase and was observed about $18 \%-22 \%$. When the temperature increases in rage of $30-35{ }^{\circ} \mathrm{C}$, infection rate reached average $35 \%$. Different from the other temperature ranges, infection rate started to decrease and in decreased rate of $25 \%$ in the range of $35-39^{\circ} \mathrm{C}$ (Table 1, Fig. 1).

According to data from humidity, the lowest humidity datum was observed as $13 \%$ in Alucra locality in July. And also, infection rate was $2 \%$ in that locality. Additionally, $82 \%$ was determined as the highest humidity rate in Ulubey locality where infection rate was $56 \%$ in June (Table 1). While humidity was in the range of $13-19 \%$, average infection rate was observed $5 \%$. The infection rates were showed increase with the humidity rates proportionally. When the humidity raised from $20 \%$ to $49 \%$, average infection rate reached from $5 \%$ to $21 \%$. Different from other humidity data, in the range of

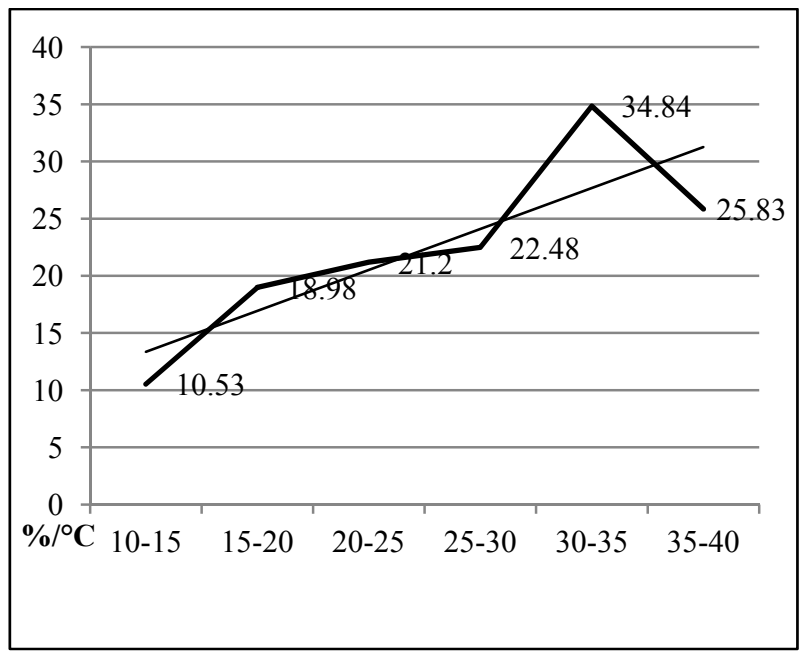

(a)
$50 \%-59 \%$ humidity, average infection rate decreased at $15 \%$. Humidity rates increased from $60 \%$ to $82 \%$, the infection rates increased again and it reached as high as $56 \%$ (Table 1, Fig. 2).

Geographical distribution of $N$. ceranae infection was studied according to the localities in different altitude. Depending on the geography of the Eastern Black Sea Region of Turkey 0-1,000 $\mathrm{m}$ and 1,000-2,000 $\mathrm{m}$ altitudes were interpreted. The total infection in high altitude localities was found to be $17.24 \%$, the total infection in low altitude localities was higher than in high altitude localities, and also it was $24.55 \%$ (Table 1). Each selected two areas in the province of Artvin were under 1,000 m altitude, and total infection rate in Artvin province was $33.33 \%$. For Rize province, there was a different situation between the infection rate $(26.57 \%)$ in high altitude localities (Ayder and Anzer localities) with the infection rate $(20.5 \%)$ in low altitude localities (Rize center and Pazar localities). In Trabzon province, the average infection rate observed as $20.13 \%$ in high altitude localities (Uzungöl and Tonya localities) was higher than the average infection rate observed as $14.35 \%$ in low altitude localities (Trabzon center, Of and Beşikdüzü localities), this situation of Trabzon province was similar with that Rize province (Table 1). The average infection rates in high altitude localities

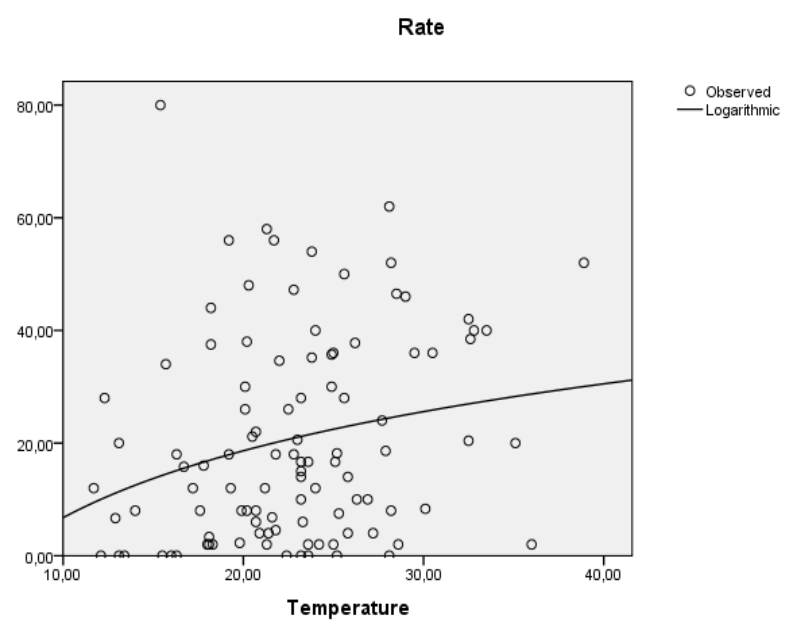

(b)

Fig. 1 The average $N$. ceranae infection rates according to changes in temperature.

Figures were made with Microsoft Excel (A) and SPSS 11.0 software (B) programs. 
516 The Effects of Temperature and Humidity around the Beehives on the Distribution of Nosemaceranae, and also Geographical and Seasonal Activity of the Infection in the Eastern Black Sea Region of Turkey

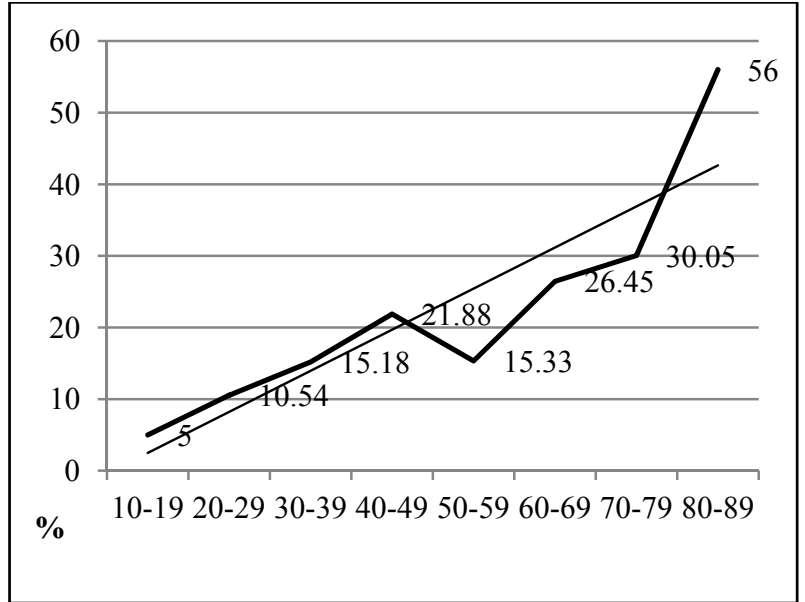

(a)

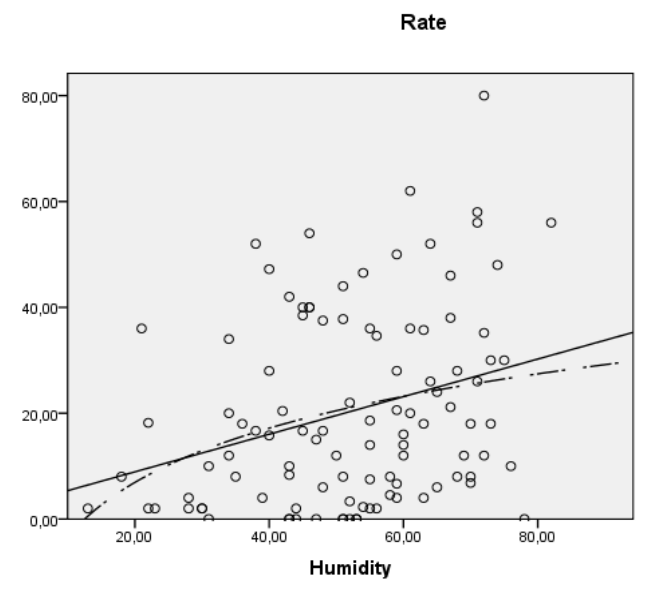

(b)

Fig. 2 The average $N$. ceranae infection rates according to changes in humidity.

Figures were made with Microsoft Excel (A) and SPSS 11.0 software (B) programs.

Table 1 Distribution of N. ceranae in A. melliferain Eastern Black Sea region of Turkey in 2011.

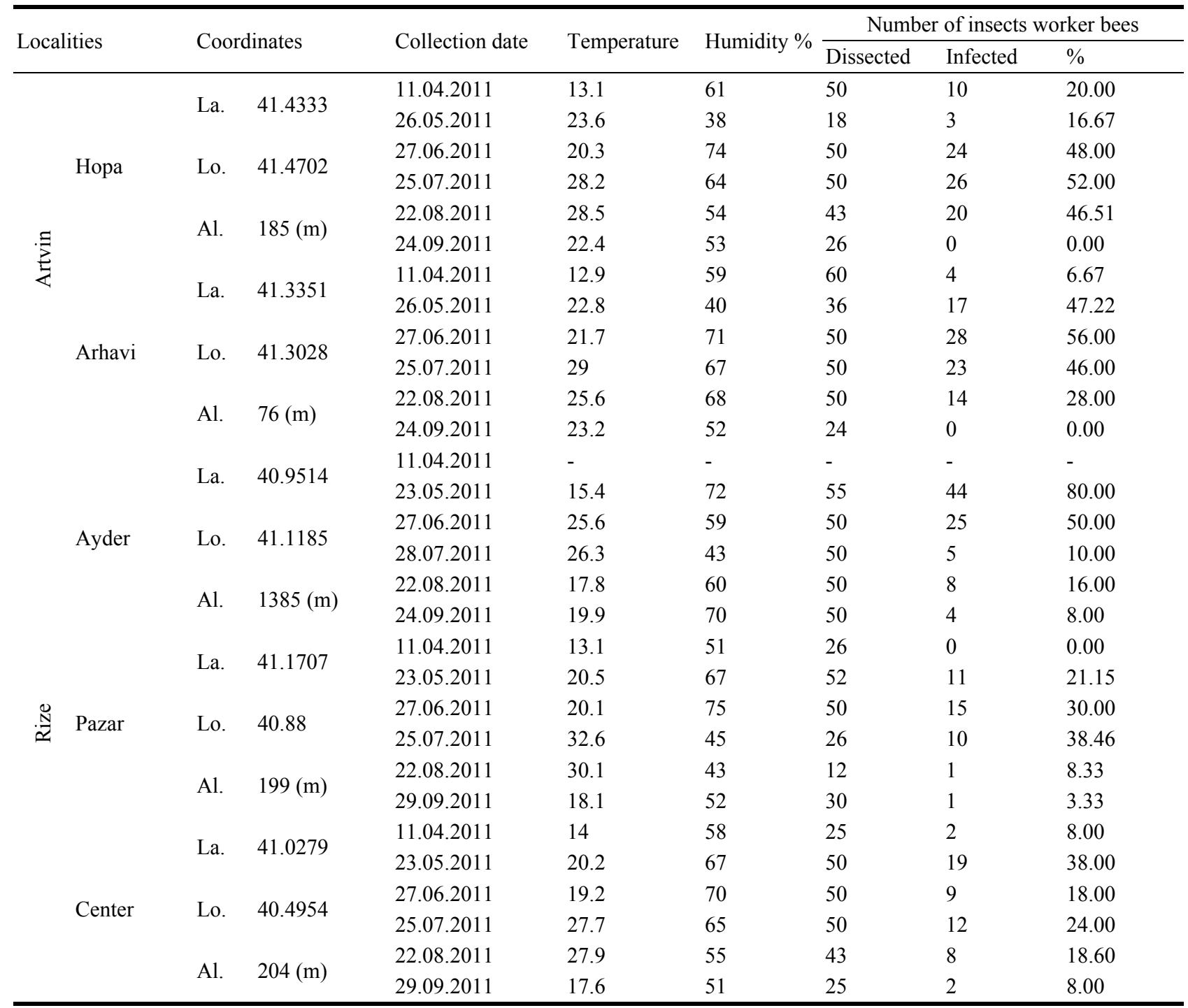


The Effects of Temperature and Humidity around the Beehives on the Distribution of Nosemaceranae, 517 and also Geographical and Seasonal Activity of the Infection in the Eastern Black Sea Region of Turkey

Table 1 to be continued

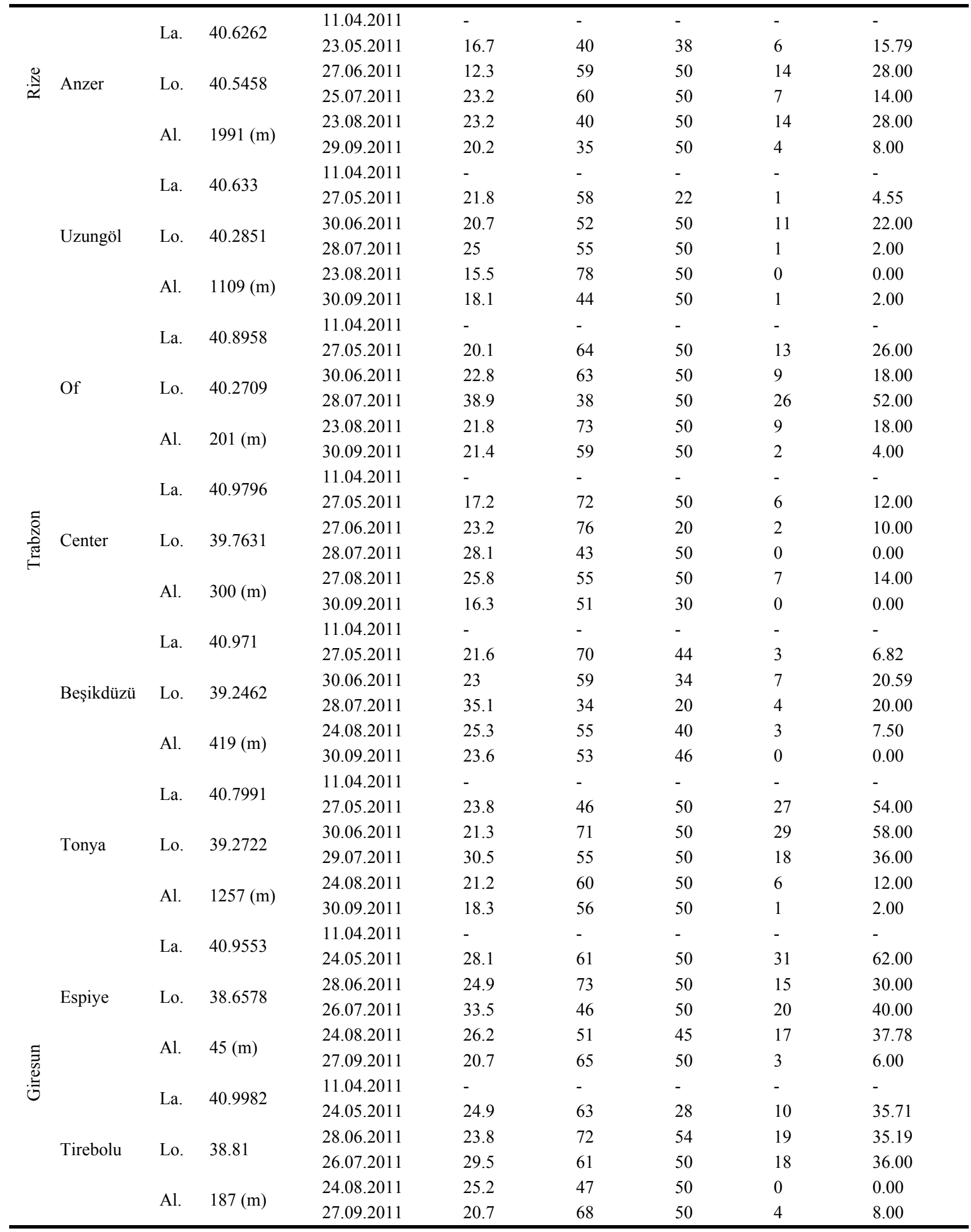


518 The Effects of Temperature and Humidity around the Beehives on the Distribution of Nosemaceranae, and also Geographical and Seasonal Activity of the Infection in the Eastern Black Sea Region of Turkey

Table 1 to be continued

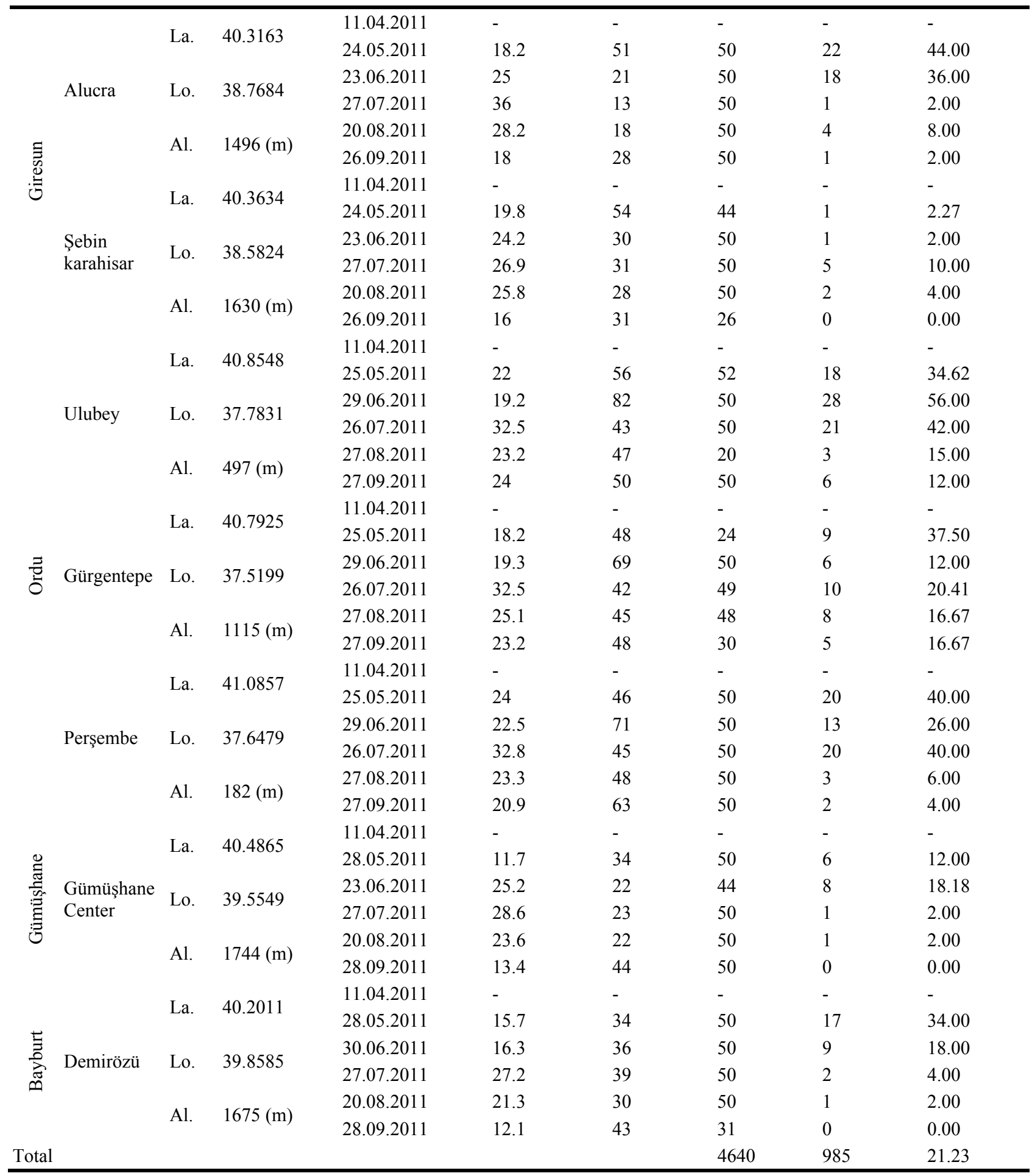

La: Latitude, Lo: Longitude, Al: Altitude.

were lower than that in low altitude localities for Giresun and Ordu provinces being different from Rize and Trabzon provinces. In Giresun province, the average infection rate in high altitude localities (Alucra and
Şebinkarahisar localities) was $11.7 \%$ and the average infection rate in low altitude localities (Tirebolu and Espiye localities) was $28.72 \%$. Similarly, in Ordu province, the average infection rates in high altitude 
The Effects of Temperature and Humidity around the Beehives on the Distribution of Nosemaceranae, 519 and also Geographical and Seasonal Activity of the Infection in the Eastern Black Sea Region of Turkey

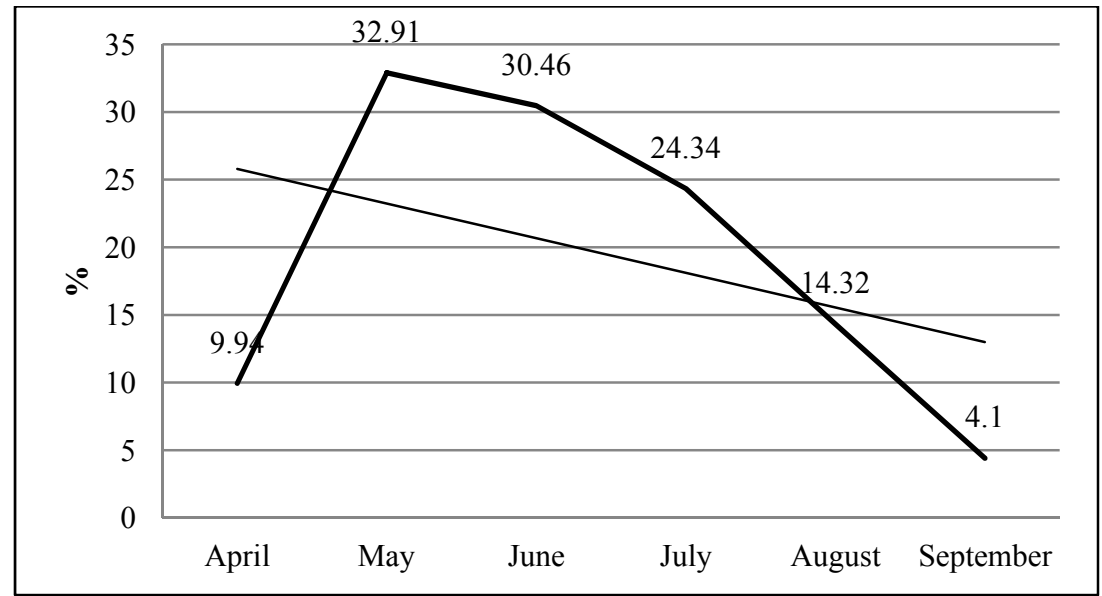

Fig. 3 The average $N$. ceranae infection rates according to changes in month.

localities (Gürgentepe locality) and in low altitude localities (Perşembe and Ulubey localities) were $18.9 \%$ and $28.38 \%$ respectively (Table 1 ). Gümüşhane center locality in Gümüşhane province and Demirözü locality in Bayburt province were directly over 1,000 $\mathrm{m}$ altitude localities and also infection rates were $6.5 \%$ and $12.5 \%$ respectively (Table 1 ).

$N$. ceranae infection rates of the examined samples showed remarkable difference from April to September. Nosemosis infection was found in every month of the six-month process. The infection rate was $9.93 \%$ in April. The highest infection rate was observed in May as $32.91 \%$. The average $N$. ceranae infection rates decreased from May to September, and also infection rates were $30.46 \%, 24.34 \% 14.32 \%$ and $4.4 \%$ respectively (Table 1, Fig. 3 ).

\section{Discussion}

In beekeeping, honey bees are affected by many kinds of environmental factors such as temperature and humidity or geographical and seasonal variations in their habitats. Besides, the pathogen and parasites of honey beesare are also affected by these environmental factors.

It can be said that for this study, Nosemosis infection significantly is affected by temperature change. Infection is directly proportional to temperature around the beehives (Pearson correlation, $\mathrm{P}<0.05, \mathrm{r}=0.245)$. References $[7,12]$ reported that temperature was a significant factor in the presence of Nosemosis infection. $N$. ceranae infection is more resistant to temperature changes than $N$. apis [13-15] reported that in his study in the laboratory conditions, $N$. ceranae spores did not lost infection activity from $4{ }^{\circ} \mathrm{C}$ to $60{ }^{\circ} \mathrm{C}$, but $N$. apis spores had less temperature tolerance. Higes et al. [16] reported that the both agent of nosemosis disease shows $99 \%$ vitality at $33{ }^{\circ} \mathrm{C}$, and also between $25^{\circ} \mathrm{C}$ and $37^{\circ} \mathrm{C}$ temperatures. $N$. ceranae shows more vitality than $N$. apis. In this study, the most infection rate observed between $30{ }^{\circ} \mathrm{C}$ and $35{ }^{\circ} \mathrm{C}$ temperatures for $N$. ceranae. Similarly in this study a very high rate of infection were determined at $30^{\circ} \mathrm{C}$ temperature around the beehives. Hive temperature is around $35{ }^{\circ} \mathrm{C}$ and this temperature is ideal for the survival of both disease agents [15]. In this study, when the temperature around the beehives was above $35^{\circ} \mathrm{C}$, decrease in the rate of infection was determined. Malone et al. [17] reported that Nosema spores that cause Nosemosis disease are able to continue the viability in the bee stool and cadavers in front of the hive, additionally temperature and humidity are important factors in contamination other bees Nosema infection.

In this study, it can be said that humidity has effect on nosemosis infection distribution likewise temperature. Infection is directly proportional to humidity around the beehives (Pearson correlation, $\mathrm{P}$ $<0.05, r=0.295)$. It is known that increased rainfall 
520 The Effects of Temperature and Humidity around the Beehives on the Distribution of Nosemaceranae, and also Geographical and Seasonal Activity of the Infection in the Eastern Black Sea Region of Turkey

increases the efficiency of humidity. Aydin et al. [12] stressed that the rainfall was an important factor on Nosema infection. Malone et al. [17] reported that $N$. apis lost the viability of infection in dry weather between $40{ }^{\circ} \mathrm{C}$ and $49{ }^{\circ} \mathrm{C}$ within 3 to 45 days. It is discussed that not only hashumidity effect on the viability of Nosemosis spores but also it increases the spread of Nosema spores and the capacity of transmitting infection to other bees [12, 14, 17].

While temperature was at low level, humidity was high and infection rate was also high in some localities for example infection rate was $80 \%$ in Ayder locality in May. Additionally, while humidity was low, temperature was at high level and infection rate was also high in the some localities for example infection rate was $2 \%$ in Alucra locality in July. It can be said that humidity was more an effective factor than temperature on distribution of $N$. ceranae. While humidity is stationary, the correlation between the temperature and the infection was found to be 0.347 (Pearson correlation, $\mathrm{P}<0.05, \mathrm{r}=0.347$ ). Additionally, while temperature is stationary, the correlation between the humidity and the infection was found to be 0.381 (Pearson correlation, $\mathrm{P}<0.05$, $\mathrm{r}$ $=0.381)$. In this case, it can be interpreted that the power of the linear relation between infection with humidity is slightly more effective than the power of the linear relation between temperature and infection. Aydin et al. [12] reports that rainfall and humidity factors, are more important factors than the temperature on infection Nosemosis. Climate changes effect on the distribution, the radiation and the presence of disease organisms in the insects [14, 18]. $N$. ceranae is more tolerant of the climate change compared to $N$. apis, Whereas $N$. ceranae showed prevalence in warm climate countries, and $N$. apisis more common in colder climates countries [19].

Detection of climatic changes plays an important role in the identification and in the struggle for Nosema disease of honey bees [20]. N. ceranae infection rate in the areas with high altitude was lower than level of infection in the areas with low altitude (Chi-Square, $p<0,05, \chi^{2}=24,057, \mathrm{df}=1$ ). The reason for this is that temperature and humidity data were variable in different altitude localities. While temperature data were close rates, there is a high difference between humidity data in low and high altitude areas. The low humidity was one of the main reasons for low levels of infection in high altitude areas.

Nosemosis infection was found in all months the process study was conducted. Infection was at very low levels in April compared to other months. The main reasons for this is that bee colonies have winter conditions due to unfavorable weather conditions in Eastern Black Sea Region in April, 2011. As for the May, in which the infection rate is at quite high level shows an increasing decrease straight accurate month of August (Chi-Square, $\mathrm{p}<0.05, \chi 2=240,04, \mathrm{df}=5$ ). The temperature and humidity factors are thought to play an important role in Nosemosis infection showing the variable results according to months. While the average temperature showed an increase, humidity declined in average between April and September in 2011. Both the temperature and humidity to decline after July were effective on decline of infection rate. In the literature, several studies reported that $N$. ceranae infection increased from April to June but decreased from September to March. In the opposite case, N. apis infection especially increased in winter months and losed its volume in summer months [21-23] studied in Virginia and Germany respectively and they reported that $N$. ceranae infection had a very high level in late spring and early summer, but it had been go down to a low level during the winter season. In a different situation, Martín-Hernández et al. [14] reported in their study in Spain, N. ceranae infection did not show a seasonal activity. $N$. ceranae especially showed activity during the summer months but $N$. apis showed activity during the winter months, because of that $N$. ceranae was more tolerant the temperature from N. apis [14, 21]. In 
The Effects of Temperature and Humidity around the Beehives on the Distribution of Nosemaceranae, 521 and also Geographical and Seasonal Activity of the Infection in the Eastern Black Sea Region of Turkey

many studies reported that $N$. ceranae seen activity in all seasons, especially it had higher levels in the summer. References $[9,14,21,24]$ discussed in their study that $N$. ceranae infection quickly replace to $N$. apis infection, because $N$. ceranae infection was more intense than N. apis in summer. Additionally, Brenna et al. [21] said that one-year period study was sufficient seasonal activity work.

The effects of temperature and humidity around the beehives on the distribution of $N$. ceranae infection, and its geographical and seasonal activity in the Eastern Black Sea region of Turkey was studied in this study for the first time.

\section{Conclusion}

The effects of temperature and humidity around the beehives on the distribution of $N$. ceranae infection, and its geographical and seasonal activity in the Eastern Black Sea region of Turkey was studied in this study for the first time.

Worker bees were examined in Eastern Black Sea of Turkey in 2011. 985 of 4,640 (21.23\%) dead worker bees which infected with $N$. ceranae were observed. Temperature and humidity data were reported separately for each locality.

While the lowest temperature datum was determined as $11.7^{\circ} \mathrm{C}$ in May in Gümüşhane center locality that it has $12 \%$ infection rate, the highest temperature datum was determined as $38.9{ }^{\circ} \mathrm{C}$ in of locality that infection rate was $52 \%$ in July.

According to data from humidity, the lowest humidity datum was observed as $13 \%$ in Alucra locality in July. And also infection rate was $2 \%$ in that locality. Additionally, $82 \%$ was determined as the highest humidity rate in Ulubey locality where infection rate was $56 \%$ in June.

The total infection in high altitude localities was found to be $17.24 \%$, the total infection in low altitude localities was higher than in high altitude localities, and also it was $24.55 \%$

Nosemosis infection was found in every month of the six-month process. The infection rate was $9.93 \%$ in April, The highest infection rate was observed in May as $32.91 \%$. The average $N$. ceranae infection rates decreased from May to September, and also infection rates were $30.46 \%, 24.34 \% 14.32 \%$ and $4.4 \%$ respectively.

\section{References}

[1] Klee, J., Besana, A. M., Genersch, E., Gisder, S., Nanetti, A., Tam, D. Q., et al. 2007. "Widespread Dispersal of the Microsporidian Nosema ceranae, an Emergent Pathogen of the Western Honey Bee, Apis mellifera." Journal of Invertebrate Pathology 96 (1): 1-10.

[2] OTB. 2008. Arıcılıkve Bal Üretimi, Ordu Ticaret Borsas1 Yayınları: Ordu.Turkish.

[3] Saner, G., Yücel, B., Yercan, M., Karaturhan, B., Engindeniz, S., Çukur, F., et al. 2011. "Organikve Konvansiyonel Bal Üretiminin Teknikve Ekonomik Yönden Geliştirilmesive Alternatif Pazar Olanaklarının Saptanması Üzerine Bir Araştırma İzmir İli Kemalpaşaİlçesi Örneği.” Tepge Yayın. Ankara: 1-50. Turkish.

[4] Paxton, R. J. 2010. "Does Infection by Nosema ceranae Cause "Colony Collapse Disorder" in Honey Bees (Apis mellifera)." Journal of Agriculture Research 49 (1): 80-4.

[5] Fries, I., Feng, F., Silva, A. D., Slemenda, S. B., and Pieniazek, N. J. 1996. "Nosema ceranae N. SP. (Microspora, Nosematidae, Morphological and Molecular Characterization of a Microsporidian Parasite of the Asian Honey Bee Apis cerana (Hymenoptera, Apidae)." European Journal of Protistology 32 (3): 356-65.

[6] Higes, M., Martin, R., and Meana, A. 2006. "Nosema ceranae, A New Microsporidian Parasite in Honey Bees in Europe." Journal of Invertebrate Pathology 92 (2): 93-5.

[7] Huang, W. F., Jiang, J. H., Chen, Y. W., and Wang, C. H. 2007. "A Nosema ceranae Isolate from the Honey Bee Apis mellifera." Apidologie 38 (1): 30-7.

[8] Martín-Hernández, R., Meana, A., Prieto, L., Salvador, A. M., Garrido-Bailón, E., and Higes, M. 2007. "Outcome of Colonization of Apis mellifera by Nosema ceranae." Applied and Environmental Microbiology 73 (20): 6331-8.

[9] OIE. 2008. "Nosemosis of Honey Bees. Chapter 2. 2. 4." in Manual of Diagnostic Testsand Vaccines for Terrestrial Animals 1: 410-4.

[10] Higes, M., Martín-Hernández, R., Garrido-Bailón, E., Botías, C., and Meana, A. 2009. "First Detection of Nosema ceranae (Microsporidia) in African Honey Bees 
522 The Effects of Temperature and Humidity around the Beehives on the Distribution of Nosemaceranae, and also Geographical and Seasonal Activity of the Infection in the Eastern Black Sea Region of Turkey

(Apis mellifera Intermissa)." Journal of. Agriculture Research 48 (3): 217-9.

[11] Webster, T. C., Pomper, K. W., Hunt, G., Thacker, E. M., and Jones, S. C. 2004. "Nosema apis Infection in Worker and Queen Apis mellifera." Apidologie 35 (1): 49-54.

[12] Aydın, L., Çakmak, İ., Güleğen, E., and Wells, H. 2005. "Honeybee Nosema Disease in the Republic of Turkey." Journal of Apicultural Research 44 (4): 196-7.

[13] Campbell, J., Kessler, B., Mayack, C., and Naug, D. 2010. "Behavioural Fever in Infected Honeybees: Parasitic Manipulation or Coincidental Benefit?” Parasitology 137 (10): 1487-91.

[14] Martín-Hernández, R., Meana, A., García-Palencia, P., Marín, P., Botías, C., Garrıdo-Baılón, E., et al. 2009. "Effect of Temperature on the Biotic Potential of Honey Bee Microsporidia." Appliedand Environmental Microbiology 75 (8): 2554-7.

[15] Fenoy, S., Rueda, C., Higes, M., Martín-Hernandez, M., and del Aguila, C. 2009. "High-Level Resistance of Nosema ceranae, a Parasite of the Honeybee, to Temperature and Desiccation." Applied and Environmental Microbiology 75(21): 6886-9.

[16] Higes, M., Garcia-Palencia, P., Martín-Hernández, R., and Meana, A. 2007. "Experimental Infection of Apis mellifera Honeybees with Nosema ceranae (Microsporidia)." Journal of Invertebrate Pathology. 94 (3): 211-7.

[17] Malone, L. A., Gatehouse, H. S., and Tregidga, E. 2001. "Effects of Time, Temperature, and Honey on Nosema apis (Microsporidia: Nosematidae), a Parasite of the Honeybee, Apis mellifera (Hymenoptera: Apidae)." Journal of Invertebrate Pathology 77: 258-68.
[18] De la Rocque, S. J., Rioux, A., and Slingenbergh, J. 2008. "Climate Change: Effects on Animal Disease Systems and Implications for Surveillance and Control." Revue Scientifique Et Technique (International Office of Epizootics) 27 (2): 339-54.

[19] Fries, I., and Forsgen, E. 2008. "Undersökningavspridningenav Nosema ceranaei Sverige. Investigation of the Distribution of Nosema ceranae in Sweden." Bitidningen 107, (januari/februari) 26-7. Swedish.

[20] Fries, I. 2010. "Nosema ceranae in European Honey Bees (Apis mellifera).” Journal of Invertebrate Pathology 103: 73-9.

[21] Brenna, E., Traver, B. E., Matthew, R., Williams, M. R., Richard D., and Fell, R. D. 2012. "Comparison of within Hive Sampling and Seasonal Activity of Nosema ceranae in Honey Bee Colonies." Journal of Invertebrate Pathology 109 (2): 187-93.

[22] Traver, B. E., and Fell, R. D. 2011. "Prevalence and Infection Intensity of Nosema in Honey Bee (Apis mellifera L.) Colonies in Virginia." Journal of Invertebrate Pathology 107 (1): 43-9.

[23] Gisder, S., Hedtke, K., Mockel, N., Frielitz, M. C., Linde, A., and Genersch, E. 2010. "Five-year Cohort Study of Nosema Spp. in Germany: Does Climate Shape Virulence and Assertiveness of Nosema ceranae?" Applied and Environmental Microbiology 76 (9): 3032-8.

[24] Higes, M., Martín-Hernández, R., Botías, C., Bailón, E. G., González-Porto, A. V., Barrios, L., et al. 2008. "How Natural Infection by Nosema ceranae Causes Honeybee Colony Collapse." Environmental Microbiology 10 (10): 2659-69. 